\title{
VI. In the Meantime: Same-sex Ceremonies in the Absence of Legal Recognition
}

\author{
Kathleen LIDDLE and Becky J. LIDDLE
}

Although the US government says we're not entitled to a state-issued certificate, we consider ourselves married. The photographs on our mantlepiece and the rainbow flag covered with guest signatures hanging in our study are tangible reminders of our ceremony. They remind us that we are anchored - not only to each other, but within a geographically dispersed community that pledged to support our relationship. Like many people in same-sex relationships, we decided to hold a commitment ceremony despite the lack of legal recognition. This decision was both political and personal.

On a political level, we see such rituals as part of the ongoing activist project that seeks equal rights for lesbian, gay, bisexual, and transgender (LGBT) people. Ceremonies cannot replace the fight for same-sex marriage or its accompanying legal rights. Issues of taxation, immigration, and healthcare remain critical for same-sex couples. However, efforts toward societal change benefit from a broad repertoire of tactics.

Sandoval's (2000) notion of differential consciousness suggests the metaphor of an automobile clutch, in which various ideologies can be invoked for action. Rather than attempting to agree on a single movement-wide strategy - an unlikely prospect - differential consciousness instead acknowledges that different challenges call for different strategies. The choice of which strategy to use becomes a tactical decision, requiring 'grace, flexibility, and strength' (p. 59). Similarly, Wolf (1991) argues that both separatist and revolutionary activities are necessary, on both individual and collective levels. Eisland (1994) argues that legislative successes must be accompanied by the reconstruction of practices and images. In embracing the value of multiple approaches to changing the world, we simul-

Feminism \& Psychology (C) 2004 SAGE (London, Thousand Oaks and New Delhi) Vol. 14(1): 52-56; 0959-3535

DOI: $10.1177 / 0959-353504040303$ 
taneously reaffirm the acceptance of diversity that we seek to nurture in mainstream society.

Holding a same-sex ceremony does not directly impact legislation. But our ceremony was, in the words of our minister, 'an act of counter-cultural rebellion'. We see the act of celebrating a same-sex union in the absence of legal recognition as an opportunity to create symbolic transformation. We believe it is important for gay and lesbian couples to claim the legitimacy of their unions, regardless of governmental recognition. Furthermore, same-sex ceremonies may help change individual attitudes, thus hastening legal recognition.

When speaking of our ceremony, we used the words wedding and marriage partly to reclaim these terms from those who contend that marriage is restricted to heterosexuals. Using these words also offered family and friends a familiar category in which to place our relationship, while simultaneously emphasizing that its value is equivalent to that of heterosexual unions.

We are fortunate to be surrounded by people who unconditionally accept both our sexuality and our relationship. The act of mailing invitations brought us no feelings of trepidation regarding how people might respond. However, even for friends and family who have always expressed support, the ceremony provided an opportunity for them to think more actively about our relationship and its significance. Through conversations that took place before and after the event, we realized that many people seemed to gain a deeper understanding both of our relationship and of the challenges we face. They heard us talk about carefully drawing up a thick stack of legal documents - our attempt to approximate the rights that would have automatically been ours upon marrying someone of the other sex. We also regaled them with more humorous stories about our quest to find a gay-friendly disc jockey and photographer. Such concrete examples provided reminders of the legal, social, and cultural obstacles that gay and lesbian couples encounter.

Other political consequences were of a more public nature. A few months beforehand, Becky mentioned our upcoming wedding to a campus newspaper reporter who called, seeking a quote on the same-sex marriage debate. With our permission, the favorable article that eventually ran used our wedding as its hook and included a photo of us. We jokingly referred to it as our 'engagement announcement', but its appearance had a more serious significance. Because of the conservative, homophobic climate surrounding this university, few gay and lesbian people were 'out' and positive media portrayals were rare. Shortly thereafter, we agreed to be interviewed for a local television news report on same-sex marriage. We didn't actively approach any media outlets with our story, but when opportunities like this surfaced we felt a desire and a responsibility to speak out. We saw this as an opportunity to affect public opinion.

Similarly, we've found that raising the subject of our marriage with homophobic individuals gives them pause. Both of us are regularly called upon to discuss gay and lesbian issues, whether in our own classrooms or as guest speakers. Describing our ceremony seems to facilitate comparison of our relationship with 
those of heterosexual spouses. Some are surprised to learn that a minister presided at our wedding, which leads to discussions about the differences between religious and civil aspects of marriage. Holding the image of a wedding in their minds sometimes makes the injustice regarding legal protections and benefits easier for them to understand.

On a personal level, the event enabled us to bring our friends and family together for a once-in-a-lifetime event. Also, both the ceremony and the process of planning it offered us an opportunity to reflect on our relationship and intentionally create a vision for our life together.

As with most weddings, our ceremony brought together geographically farflung friends and family. Weston (1991) notes that lesbian families often include both chosen family and family of birth, with the two circles remaining quite separate. We planned the celebration to take place over the course of a long weekend, intentionally creating a space for the weaving of these two groups, including both Becky's biological family and Kathy's circle of friends that serve as her surrogate family. We watched with joy the conversations, card games, and general camaraderie that emerged. Now we feel that our family structure is less fragmented, since wedding attendees have met each other and have shared memories. Perhaps more importantly, Kathy had the experience of hearing Becky's relatives formally welcome her to the family during the ceremony, while Becky was equally enthusiastically adopted by Kathy's circle.

Our carefully planned ceremony included both personal and political messages. We addressed the level of commitment we were making and our expectation that our loved ones would treat it like any heterosexual marriage. We included not only vows to each other, but also vows that we offered to our guests - such as the promise that our home will be a place of warmth and comfort, where there is always room for one more at the table. In turn, we asked them to participate in a responsive 'Call to Community' modeled after one written by our dear friend, Lisa Bashert. Lisa and her partner Beth read aloud a series of statements regarding difficulties faced by lesbian couples, pausing after each for the congregation to recite a supportive response. For example,

Leaders: Because we do not receive the benefits and protections offered to those whose marriages are sanctioned by the state...

Congregation: . . . we will do our part to correct these inequities. We will work creatively to find solutions to the barriers set against you.

Hearing these voices collectively raised in affirmation was powerful to us and others. One friend credited this moment with giving her the courage to go home and write a long overdue coming out letter to her family.

For Becky, an intriguing aspect of the ceremony was that it diffused the resentment she previously felt toward attending heterosexual weddings. Oswald (2002) suggests that, 'because weddings embody the legal, material, family, religious, and social benefits that our society denies GLBTQ [gay, lesbian, bisexual, trans- 
gender, questioning] people . . . weddings are deeply problematic for GLBTQ family members' (p. 327). Previously, Becky harbored some resentment about the accompanying travel and gift-giving. She believed that as a lesbian she would never have a wedding, so the gestures would not be reciprocated. After witnessing the unequivocal outpouring of support at our ceremony, she finds that her resentment of heterosexual weddings has evaporated. Weddings now just bring back happy memories of our own celebration. In contrast, Kathy never experienced such resentment, perhaps due to the difference in our ages and the societal changes that occurred in the interim. She attended a same-sex ceremony for the first time during college, allowing her to internalize at a younger age the idea that rituals could be created and enacted for any relationship. Of course, both of us still harbor deep resentment about the political discrimination that denies us the rights associated with legal marriage.

Some may argue that we bought into heterosexual hegemony by holding a wedding, but we find this assumption too simplistic. Believing in the importance of ritual, we created an event to mark a life-altering, joyous decision, including only what felt personally meaningful to us. Although Kathy changed her last name, it was not as a sign of submission or from a feeling of being held to tradition. Rather, she sought to distance herself from a difficult past and to symbolically mark her choice of a new family. To inject a moment of levity, Becky threw a tool belt instead of a garter or a bouquet of flowers. Our guests signed a rainbow flag instead of a guest book. The ceremony itself reflected our values and life circumstances as a lesbian couple. The time we spent choosing readings that spoke to us, carefully considering what to include in our vows, and deciding how best to honor the people closest to us, was an extended meditation on our relationship - its current strengths and future visions.

We do not suggest that a ceremony is desirable - or feasible - for everyone. Our preference was to mark our commitment with a ritual. It is our good fortune that we find ourselves surrounded by people who did not hesitate to express their joy for us and who willingly traveled great distances to honor us. Becky's parents generously paid for the wedding, allowing us a celebration that we could not have afforded otherwise. We acknowledge that we had not only the desire but also the privilege to make this choice. In doing so, we created memories that sustain us, forged a blending of family, and experienced an infusion of energy that continues to affect us on personal, social, and political levels.

Neither do we believe that our model of relationship is the best or only one. Long-term monogamy is only one of many viable relationship choices, just as holding a public celebration represents only one approach to acknowledging a relationship. As Karin Luetzen (1998) asserts, 'the radical potential of homosexuality as a manifestation of the variety of lifestyles should not be jettisoned in the name of politics of assimilation' (p.233). We agree that care must be taken to ensure that any victories in the struggle for same-sex marriage rights not be transformed into imperatives.

We do, however, believe that legalized same-sex marriage should be an option. 
In the USA, married heterosexual couples gain access to a plethora of rights and privileges. While our long-term hope is that society can be reconfigured so that important rights - such as access to healthcare - are not tied to marriage, we know this is a long way off. We believe that marriage rights must be extended in order to provide same-sex couples with equal rights while efforts at broader social change are under way. Once legalized same-sex marriage becomes an option, we will join many other gay and lesbian couples in exercising that right. In the meantime, the personal, social, and political implications of public unions are substantial enough that many of us choose to hold them regardless of whether they are legally recognized.

\section{REFERENCES}

Eisland, N. (1994) The Disabled God: Toward a Liberatory Theory of Disability. Nashville, TN: Abingdon Press.

Luetzen, K. (1998) 'Gay and Lesbian Politics: Assimilation or Subversion: A Danish Perspective', Journal of Homosexuality 35: 233-43.

Oswald, R. F. (2002) 'Who Am I in Relation to Them? Gay, Lesbian, and Queer People Leave the City to Attend Rural Family Weddings', Journal of Family Issues 23: 323-48.

Sandoval, Chela (2000) Methodology of the Oppressed. Minneapolis, MN: University of Minnesota Press.

Weston, K. (1991) Families We Choose: Lesbians, Gays, Kinship. New York: Columbia University Press.

Wolf, N. (1991) The Beauty Myth: How Images of Beauty are Used against Women. New York: William Morrow.

Kathleen LIDDLE is a doctoral student in Sociology at Emory University in Atlanta, Georgia, where she studies culture, social movements, and organizations. Her current research projects focus on feminist bookstores in the USA, the repertoires of US symphony orchestras, and women in music.

ADDRESS: Department of Sociology, Emory University, 1555 Pierce Drive, Suite 225 Atlanta, GA 30322, USA.

[email: kliddle@emory.edu]

Becky J. LIDDLE is an associate professor of Counseling and Counseling Psychology at Auburn University in Auburn, Alabama. Her research focuses on LGBT issues in psychotherapy and in the workplace, as well as other issues of prejudice and privilege.

ADDRESS: Department of Counseling \& Counseling Psychology, Auburn University, Auburn, AL 36849-5222, USA.

[email: liddlbj@auburn.edu] 